\title{
Castor bean oil and the matrix of energy in Brazil
}

\author{
Óleo de mamona e a matriz energética brasileira
}

Received: 08/31/2021 | Reviewed: 09/03/2021 | Accept: 09/09/2021 | Published: 09/10/2021

\author{
Isabel Lausanne Fontgalland \\ ORCID: https://orcid.org/0000-0002-0087-2840 \\ Federal University of Campina Grande, Brazil \\ E-mail: isabel.fontgalland@gmail.com
}

\begin{abstract}
This article aims the National Program of Production and Usage of Bio Combustibles- Brazil (PNPB with the castor bean crop as a favorable candidate for increasing the production of small rural properties, as well as the construction of a sustainable energy policy. Throughout the study, the policies and techniques of this Brazilian institutional arrangement pointed to castor oil as being suitable for farmers in the Brazilian Northeast. In the article, it is also verified some of the arrangements that combine local energy demands with the new technical elements for conducting a balance between biofuel and fossil fuel. This being the most efficient policy. The decision on the allocation of efficiency, in the case of the energy sector, has many concerns within the energy matrix. As a result, what was just a research problem, became the crucial point of commitment of the Brazilian energy agencies, both in the sense of expanding a platform of biofuels consortia as well as promoting incentives through the force of law. Considering that, since the 1990s, renewable energy sources are the main issue around the world, then the question is whether castor bean-based biofuel is a good source of efficient green energy? Who prepares this oilseed for future generations? What kind of by-products can this supply chain develop? To answer all these questions, the DEA method offered many insights into the new range of sector policies through the CONAB-Brazil database.
\end{abstract}

Keywords: Brazil; Castor bean oil; Environmental Policy.

\begin{abstract}
Resumo
Este artigo aponta o Programa Nacional de Produção e Aproveitamento de Biocombustíveis (PNPB), tendo a cultura da mamona como candidata favorável ao incremento de produção da pequena propriedade rural, bem como a construção de uma política energética sustentável. Ao longo deste estudo, as capacidades políticas e técnicas do arranjo institucional brasileiro, apontaram para o óleo de mamona como sendo vocacionado aos agricultores do Nordeste brasileiro. No artigo verifica-se também alguns dos arranjos que combinam as demandas locais de energia aos novos elementos técnicos de condução de equilíbrio entre o biocombustível e o combustível fóssil. Sendo esta a política de forma mais eficiente. A decisão sobre a alocação de eficiência, no caso do setor de energia, tem muitas preocupações dentro da matriz de energia. Ao invés, ser apenas um problema de pesquisa, tornou-se o ponto crucial de empenho das agências brasileiras de energia, tanto no sentido de ampliar a plataforma de consórcios de biocombustíveis bem como fomentar incentivos via força de lei. Considerando que, desde a década de 90, as fontes renováveis de energia são a principal questão em todo o mundo, então, questiona-se se o biocombustível à base de mamona é uma boa fonte de energia verde eficiente? Que potenciais apresentam esta semente oleaginosa para as gerações futuras? Que tipo de subprodutos essa cadeia de suprimentos pode desenvolver? Para responder a todas essas perguntas, o método DEA ofereceu muitos insights sobre a nova gama de políticas do setor através da base de dados da CONAB-Brasil.
\end{abstract}

Palavras-chave: Brasil; Óleo de mamona; Política ambiental.

\section{Introduction}

For more than 100 years fossil fuels have been leading the industrial development of the global energy matrix. Therefore, many studies suggest the use of biomass for energy purposes. Importantly biomass are all biological organisms that could be used as sources of electrical energy: sugar cane, eucalyptus, beet (of which alcohol is extracted), biogas (produced by anaerobic biodegradation in the trash and existing organic waste), wood and charcoal, some vegetable oils (groundnut, soybean, palm oil, castor oil, etc. Ramos, 2003). Consequently, in those two lasts two decades has happened in the worldwide, important discussions about environment and international decisions regarding sustainability and alternatives sources of energy. After 1994, many agencies, specifically in Brazil, have been studying about a green fuel named castor bean oil as a perfect substitute for fossil fuel 
and energy. According to Parente (2003), castor bean seed ("mamona') is denominating — very high standard of pure biodiesel, renewable, biodegradable and environmentally correct. As a perfect substitute to the mineral diesel oil, constituted of a mixture of methyl ethers or ethylic long chain acids, obtained from the reaction of transesterification of any triglyceride with an alcohol of short chain (using methanol or ethanol).

As an introduction, biodiesel is one of the components of the Brazilian energy matrix. Despite this, the discussions took a first order of importance considering the potential of Brazilian oilseeds and the geographic area that is devoted towards alternative sources of energy. For this, was done initially, a discussion about the limits of oil as the main energy source of the current industry standard and subsequently demonstrated the historical evolution of global research and use of it as fuel. Nowhere, the focus of this article is to present the motivations around castor bean seed as a source of energy and biofuel. Further, this study can project the importance of the inclusion of this oilseed as an opportunity for a business to be highly valued.

\section{Brazilian Farmland and Castor Been Oil}

Considering the state of poverty of many small family farms in Northeastern part of Brazil, the plantations of castor bean seed have been seen as object of federal policies ${ }^{1}$ in two ways: 1 - to increase and protect small plantations, and 2 - to rise up the number of producers of castor bean seed.

Recent studies managed by EMBRAPA - BRAZIL (Brazilian agricultural agency of development) have shown particular interest in biofuels. In spite of that, its researches have pointed to the castor bean oilseed as a perfect substitute of fossil combustibles compared to canola and jatoba. The increasing production of castor bean seed in the northeast part of Brazil has amplified the discussion about its biofuel and the production capacity in other regions in the country. The assumption of a new matrix of energy in Brazilian territory has induced a new model of public policies adopted since 2003.

The development of biofuels, however in Brazil, has impacted in many discussions about the future of the highly industrialization in other countries as well as producers of biofuel as well. As an example, Brazil and The United States have invested more than 500 million dollars in 2009 e 2010 in association. Castor bean seed as one of its major importance is also related to diminution or elimination of several effects such as greenhouse gases and acid rain. An unintended, but important advantage to a castor bean project is this crop can absorb carbon dioxide, thereby reducing greenhouse gas accumulations in the atmosphere. The estimated carbon dioxide absorption level of castor bean plants is $34.6 \mathrm{mt} / \mathrm{ha}$, with two growing cycles per year. Nonetheless, castor oil is the best substance for producing biodiesel because it is the only one that is soluble in alcohol and does not require heat and the consequent energy from other vegetable oils in its phases. Hybrid Castor yields seed that contains more than $50 \%$ oil, which is rich in triglycerides, mainly ricinolein and provides a great natural resource for biodiesel production. It has two-fold environmental benefit of growing trees that store carbon while producing oil for fuel considering castor bean oil as a mail crop: It will grow on land not fit for food crops. No direct competition with existing farmland as it can be grown on degraded and marginal land. As a confident source of biodiesel it has high oil, content more than $50 \%$ and can grow on malnourished soils (Parente, 2003). The main advantages of Hybrid Castor are the high recovery and quality of oil. It is easy to grow and is resistant to drought. Nevertheless, it has great opportunity for agricultural development in arid and improved areas throughout the tropics and subtropics globally.

Brazil is seen as meaningfully strong worldwide in policies of maintenance of social programs anchored by a continuation of a small farmer production, following an important reduction of production taxes and interest. The core strategy

\footnotetext{
1 The main motivation nowhere is to present Castor bean oil as advantageous for the poorest region in Brazil and growth of the small farmlands and creation of advantages to increase revenue.
} 
has focused on the supply structure chain around oil seeds with objectify to promote transfers of income and increasing employment in rural areas. The social benefits are adoption of biodiesel of castor bean as fuel, stability of small farmlands and small interest and taxes consumed. Likewise, Brazil is actually the third biggest producer of castor bean seed which is the main product in actual scenario to promote gains of frontiers and international advantages.

During the 1990s the strategic alternatives for maintenance of intensive energy in the intensive industry standard had considered only two specific crops: ethanol corn or ethanol cane-sugar. All research developed furthermore had an impact on the new plants of oil consumption for the twentieth century. Therefore, the significant impact was in 2004 when the global reserves of petroleum felt down (Pires, 2004). Without too many sources many federal policies opted for long term policies of alternatives benefits in terms of energy and fuel.

\section{Methodology}

The focus of this study was acknowledging the principle of accessibility. According Ingram (1971) is defined as a characteristic (or advantage) inherent to a location with respect to some form of resistance to motion. There was still the concept of two types of Accessibility: the relative affordability - which reflects the connection between two points, and the Full accessibility - which reflects the degree of connection between a point and all other points of the same area.

The oilseed castor was highly produced in the semiarid Northeast region in Brazil and its relationship with the matrix of energy. Despite this, some tables and graphics are going to present its potentiality and the state of production in units of production, previously chosen as efficiently and in which is presented the best correlation of input and out-put. Nonetheless, the choice of its production units has been considered as a requirement for the best social impacts on the region under study, Northeast Brazil, and it is also possible to establish additional constraints, such as the minimum number of producers to be included in the planned chain. A model was finally chosen as a practical application of this study here now, DEA model - Data Envelopment Analysis (DEA) is a relatively new "data analysis oriented", which describes the performance of a set of peer entities called outputs. The definition of a DMU (Decision Market Units or efficient firms) is generic and flexible, because it offers many possibilities to work with the complex (often unknown) nature of the relations involving some variables: time, inputs, outputs and decisions of the Units Firms. The huge consideration in this study was identifying better benchmarks for those chosen units and the DEA model is very helpful because the small units can represent a good performance such as suggested by Cooper, Seiford \& Tone (2000).

Regarding the method DEA, the core of the model is to determine the efficiency of productive units (DMU's - Decision Making Units), pondering by the results which were produced (outputs) in relation to available resources (inputs).

Nevertheless, two important decisions must be taken in consideration when the model chosen is DEA: efficiency and relative efficiency of the DMUs. Efficiency is the best Unit improvement in the amount of time considered and relative efficiency is the relation between input and output considered for a given firm. Well, the assumptions of the model included that the DMU gains weights which are supposed to reflect the relative importance of the different inputs or outputs in which one. It also avoids the need for explicitly specifying the formal relations that are supposed to exist between inputs and outputs. This basic kind of efficiency, referred to as "technical efficiency" in economics can, however, be extended to other kinds of efficiency when data are small or have insufficient effect of gain weights.

Therefore, it has numerous studies analyzing product performance, ratio analysis and DEA. Hansen \& Wernerfelt (1989), integrated the economic model and the organizational model which are two simple models of firm performance including DMUS sized: 6-12-18. The result of their study showed that some organizational factors are better than others, in terms of changes in firm priority. 
Nonetheless, another technique widely discussed in the DEA frontier is the inverted production function, which arose from eliminating the need for efficient falsely DMU's efficiency frontier. The weakly efficient DMU's occur quite frequently due to an extremely benevolent DEA that allows the choice of zero weights to certain criteria, thus providing a large number of DMU's tied with $100 \%$ efficiency. This technique consists of pessimistic assessment of production units. The DMUs cannot display poor performance; It's required to be the best in year/examination. This restriction is respected due to inverting the inputs to the outputs. Thus, using the efficient frontier seeks what are best criteria (outputs) of each DMU, while the inverted frontier exposes what are worse the same criteria for DMU's. With this, it is obtained by a border composed DMU's the worst practices management, so it is called inefficient border, combined with the best practices, so that the most efficient in this case is the most accessible.

Figure 1-Classical and inverted frontier DEA/ BCC.

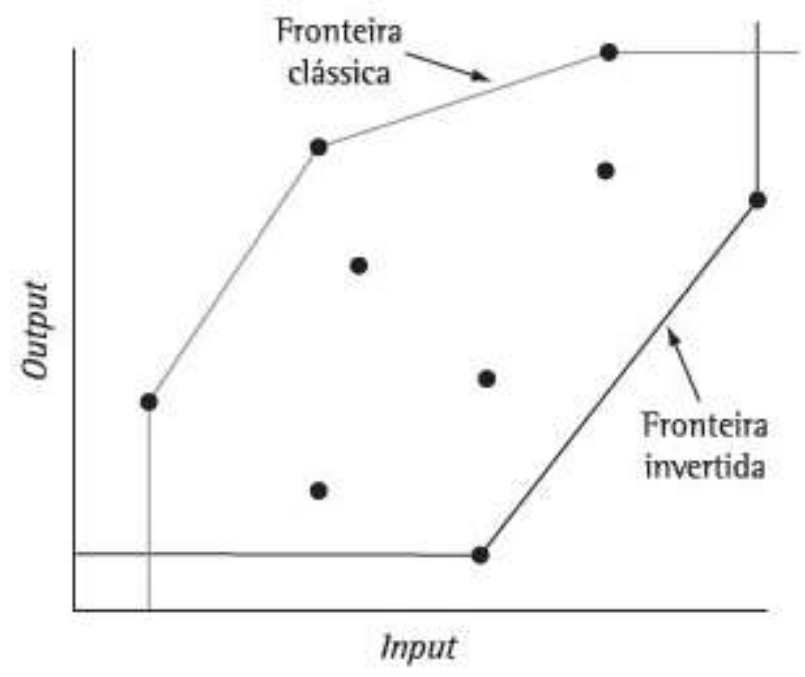

Source: Author.

The basic measure of efficiency is the ratio between one output and one input, which can be written as:

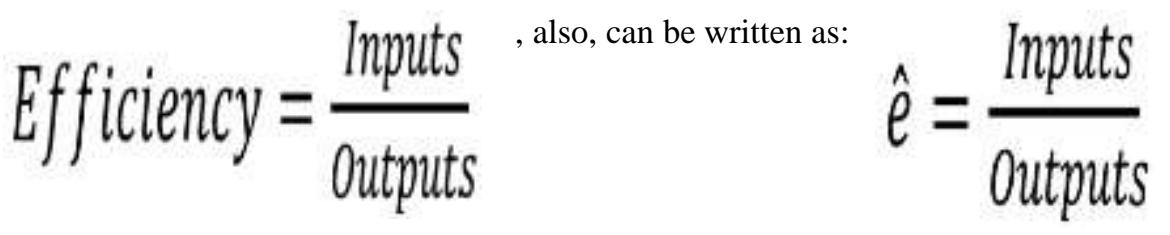

However, this equation is normally not adequate to be applied in the real-world problem because there pre-exist a numerous inputs and outputs of different categories such as hectares, capital, labor and technologies, whether we apply for the energy sector.

The fundamental behind this model is a linear programming approach which is defined as the problem of maximizing or minimizing a linear function subject to linear constraints.

Nevertheless, in the market it is needed to insert some restrictions that include:

Each of weight inputs and each of the weights of outputs must be greater all equal to zero;

For each of the DMUs the ration of the sum of the weighted output factors

$\theta y_{i} / y_{\mathrm{j}}=1$; This indicates that the efficiency score of DMUs would always be less or equal than 1 . If the ratio achieves 1 , it indicates that this DMU is fully efficient, compared to the rest DMUs in the group. The lower the ratio is the less efficient the DMU is. A unit conceived as a DMU as a firm that optimizes the input over an efficient effect output. 


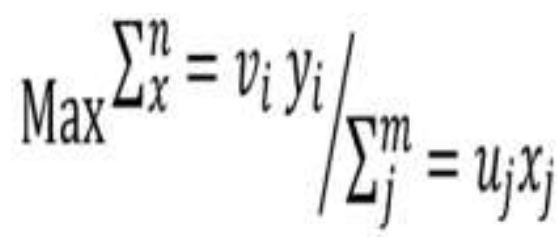

that:

$$
\frac{\sum_{x}^{n}=v_{i} y_{i}<1}{\sum_{j}^{m} u_{j} x_{j}}
$$

Where:

$\mathrm{K}=1$ to $\mathrm{S}$

$\mathrm{J}=1$ to $\mathrm{m}$

$\mathrm{Q}=1$ to $\mathrm{n}$

$\mathrm{Y}=$ amount of output produced by DMUx;

$\mathrm{Xn}=$ amount of input produced by DMUq;

$\mathrm{Vk}=$ weight given to output $\mathrm{K}$;

$\mathrm{Uj}=$ weight given to output $\mathrm{J}$.

In the case of the present study, the usage of the DEA model is to show one scale of efficiency in the Northeast region in Brazil through 10 DMUs observed. Following the assumption that castor bean oil is a potential perfect substitute to petroleum, the historical series from CONAB shall show the effects in Function Production. The construction of the DEA model here proposed shall suggest biannual data production with the two specific showings:

- Regional location.

- Capacity of agricultural dimensioning - geographic distribution of the production and area occupied.

\section{Results and Discussion}

The high potential alternative of Castor bean oil points that its seed is very valuable in different market-prices. In the medical field, blood filters, and internal and external body pumps and bone prostheses can be made of Castor bean resin, a lighter material than platinum with no observed rejection problem (Azevedo et al., 1961). The oil is also used in the car and construction industries, in coatings, special paints, varnishes, detergents, candles, synthetic products, adhesives, isolating resins, special glues, and grease for ships, cosmetics, contact lenses and to assist fluid dynamics in hydraulics.

Brazil appears in the head of that specific research through the past two decades. The Brazilian National Program of Biodiesel put in relief three points: a- full tax exemption, b-mandatory blending of $25 \%$ of biodiesel with gasoline and introduction, named flex-fuel composition in the automobile sector. Since 2003, the combination between automobile and oil industries made a trial to produce autos bi-flex motors. Also, the Federal Government amended in 2005, the exclusive right of the federal government to legislate about green energy in the country. Case studies on bioenergy policy and law: options for sustainability 87 on production and consumption, the preservation of nature and liability for damage to the environment are held concurrently by the federal government, the states and the federal district, with the role of the federal government being limited to the provision of general rules and that of the states to supplement them. With the highly centralized role played by the federal government concerning the commercialization of the energy and the logistics of transportation, most bioenergy policy prioresses 
the external trades and the international value market. However, as bioenergy has become an ever-greater political hot-button issue of late, this has begun to change and increasingly has involved new environmental regulation of bioenergy. Due to the complexity of Brazil's legal framework and regulations at the state and municipality levels, this study will be limited to federal regulations on bioenergy.

As a tropical plant, castor beans have shrubby habits and spiny fruits. Good adaptability to climatic conditions in the Brazilian northeastern ${ }^{2}$. However, this does not necessarily mean high yields. In historical context, this is the region that has lower yield per hectare, $523 \mathrm{~kg} / \mathrm{ha}$ in 2009 . This situation gives rise to research agronomic towards the development of more productive cultivars for semiarid. The objective of the government to give incentives to castor bean crop combines two fronts: creating sustainable alternatives for energy generation and structuring of the supply chain in order to generate jobs and income for farmers. The program emphasizes the use of the labor family, whose characteristics of productive organization generated practical problems unfeasible, even today, the production of castor in various properties.

As it is known, Brazil has been considered a leader of production of biodiesel since 1970, with ethanol sugarcane. Clearly, the economic acceleration is due to substantial support of governmental programs which including farms families in the states of Ceara, Bahia, Paraíba e Rio Grande do Norte. Achieving near self-sufficiency in energy production has driven the Brazilian government to begin concentrating on other objectives for the bioenergy sector, with social and environmental sustainability goals being increasingly prioritized in recent years. The Brazilian Agroenergy Plan 2006-2011outlines these new objectives, stating that Brazil's primary aim in this sector is to "produce and transfer knowledge and technologies that contribute to the sustainable production of energy from agriculture". According to CONAB - Brazilian Company of agricultural goods supply, the production of castor bean oil was very much affected by the scarcity of funds. Many farmslands were deactivated in the past decades and the resources were converted to The PETROBRAS Company - Petroleum Brazilian Company which was in large scale producing in the worldwide, petroleum, natural gas and diesel. What as seen in the table below is a historical series of areas planted in states of Northeast Brazil and strong presence of the state of Ceara and Bahia state as representative of increasement of the castor bean crops. The state of Ceara, in particular, as one case extremely important because of the presence of the Institute Expedito Parente, which stands its name in tribute to the Brazilian creator of the biodiesel molecule.

2 Well adapted to the arid climate, the plant grows in deep and well drained soils with a pH of 6 medium and rich nutrients. The planting season occurs between October and December, requiring moisture for the period of flowering and fruiting. 
Graphic 1: Historical Serie of plantation area.

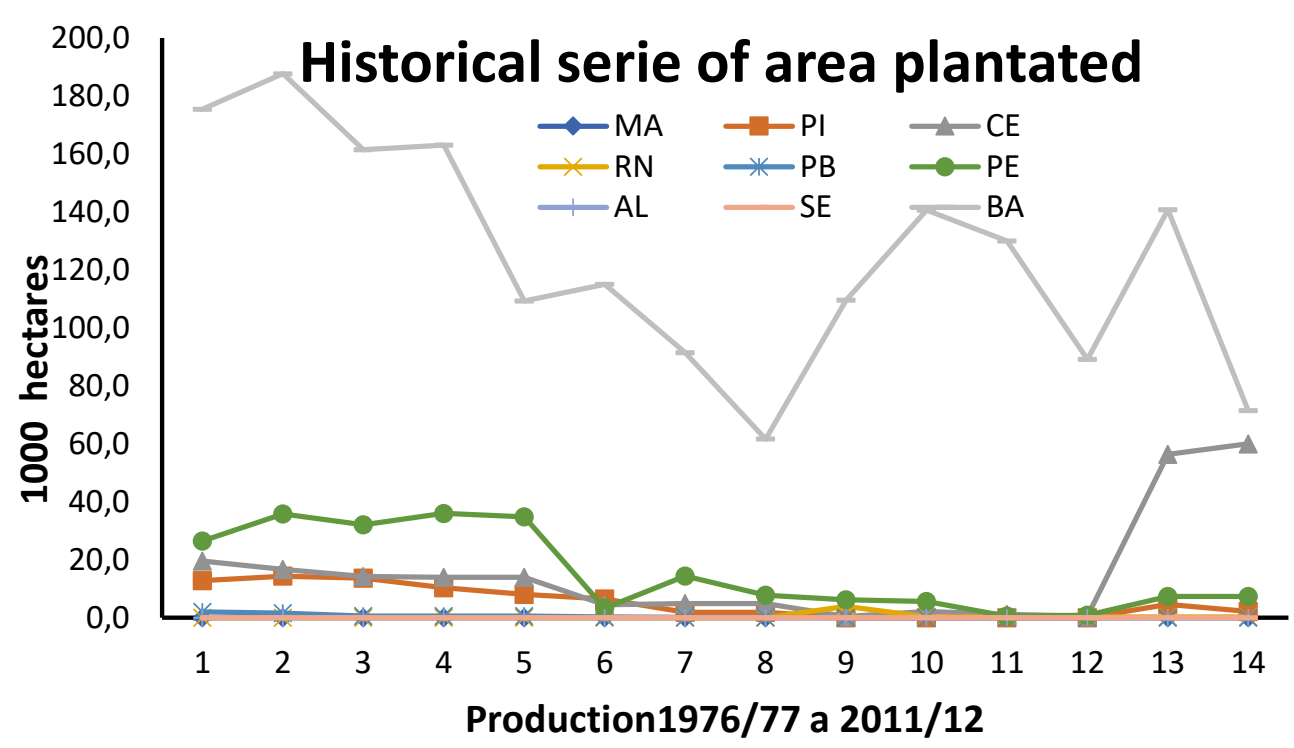

Source: Author.

With the new federal plan of agriculture survival implanted in 2003, the reality of the farmland was radically changed. In Graphic 2, the state of Bahia received the highest funds in the Northeast region and appears as one of the leaders in the region. Considered one of the richest States, Bahia, also has one the biggest oil drilling bacon.

Graphic 2: Northeastern states producers of castor bean.

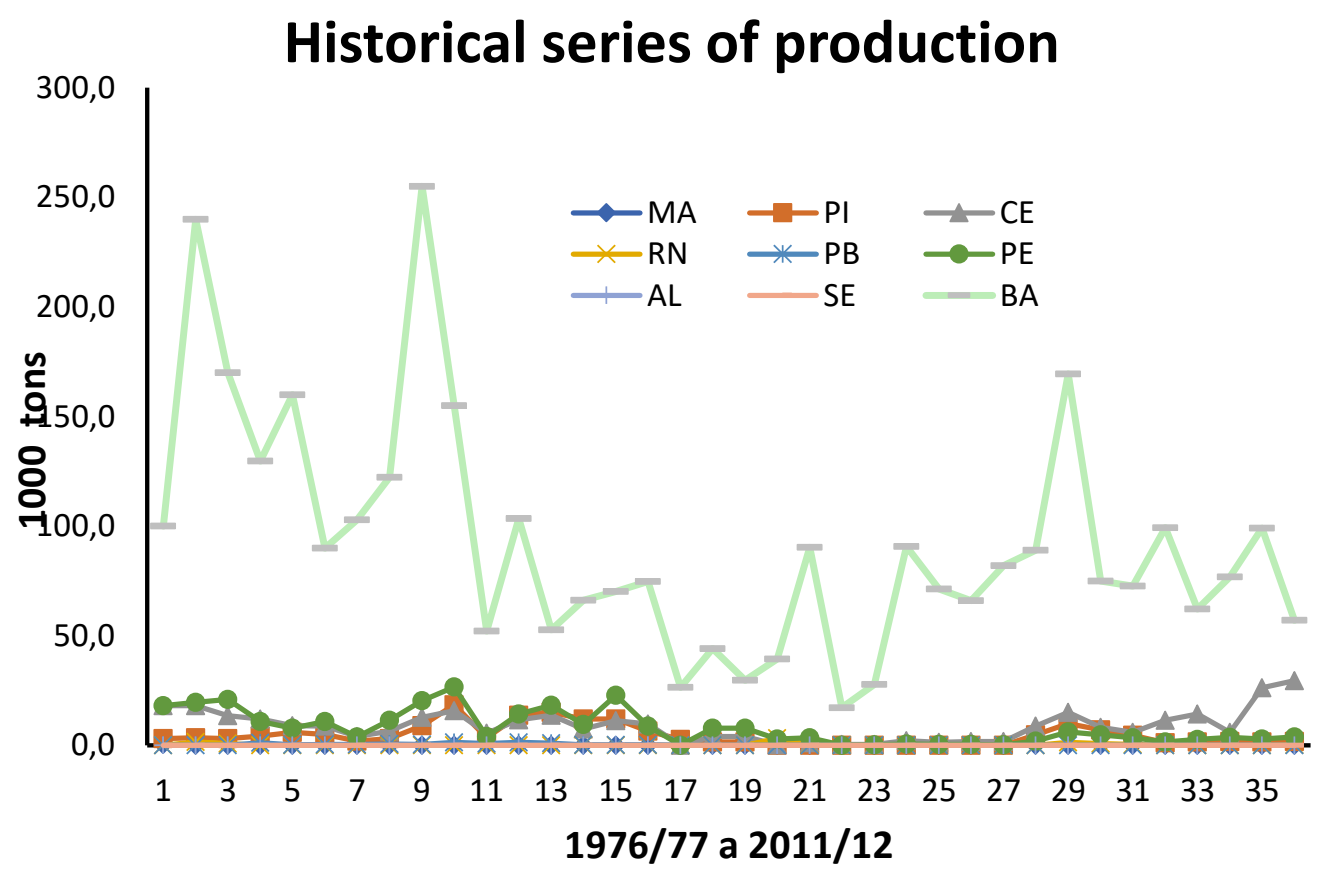

Note: CONAB/historical series 1976/2012. Source: Author.

However, the evaluation of the profile of the growth of production for the years 1990 to 2010 showed a very weak tread, which explains the absence of investment during all periods before 2003. 
Graphic 3: Evolution of production.

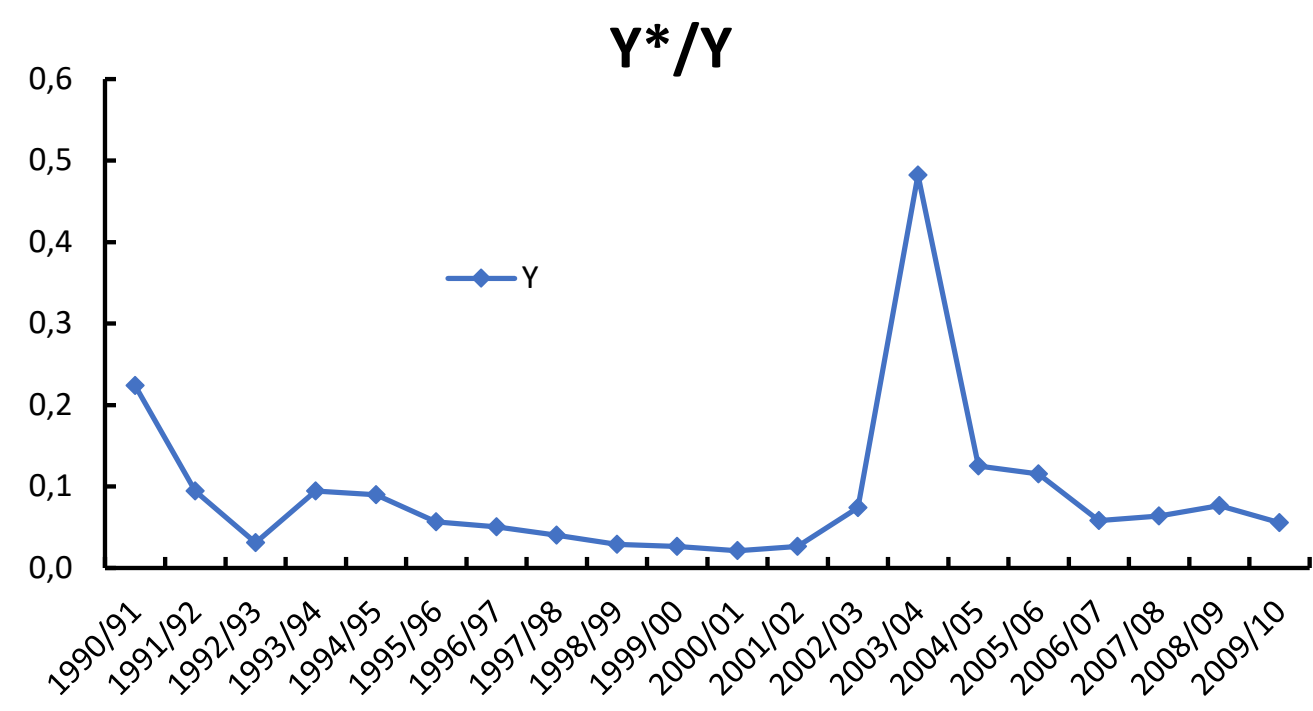

Source: CONAB, historical series. LOGIT process.

During the years 1990 to 2002, the production evolution had presented linear evolution. However, in the years 2002 to 2007, when the project of biofuel was shot down using federal research the evolution had presented expressively higher.

\subsection{DEA results}

Technically the production function using data from CONAB - Brazil this stochastic model showed that years and production are completely independent hence the term of stochastic frontier was distributed considering the most important refineries in Northeast Brazil. Likewise, the season of castor bean is very irregular which explains the difficulties to build a good notion of mathematical frontier. Basically the t productivity of the activities of production of oil is represented by the enterprises firms 1-10 which used inputs with values given by the vector $x_{1}$ and obtain the output $\mu$, but the frontier output, v, exceeds the values on the deterministic production function $\mathrm{F}(\mathrm{x} 1, \beta)$, because of its productivity.

Assuming that the frontier model has inference about the parameters of the model the conclusion is the conditions hold for a distribution non-negative of $\mu_{i}$ and a standard deviation in terms of $v_{i}$.

Table 1: DEA results.

\begin{tabular}{|l|l|l|l|l|l|l|l|l|}
\hline DMU & $\mathrm{Y}$ & $x_{1}$ & $x_{2}$ & $\frac{x_{1}}{y}(\mu)$ & $\frac{x_{2}}{y}(v)$ & Average & $\mathrm{R}$ & $\beta$ \\
\hline 1 & 80 & 161 & 49.5 & 2.020 & 0.61875 & 109 & 1 & 0.5 \\
\hline 2 & 72 & 126 & 57.4 & 1.750 & 0.7972 & 109 & 1 & 0.3 \\
\hline 3 & 86 & 128 & 67.3 & 1.480 & 0.6093 & 109 & 1 & 0.4 \\
\hline 4 & 107 & 166 & 64.3 & 1.550 & 0.6009 & 109 & 1 & 0.4 \\
\hline 5 & 210 & 215 & 97.5 & 1.024 & 0.4642 & 109 & 1 & 0.3 \\
\hline 6 & 104 & 148 & 70.3 & 1.420 & 0.6759 & 109 & 1 & 0.3 \\
\hline 7 & 104 & 156 & 60.2 & 1.500 & 0.5788 & 109 & 1 & 0.2 \\
\hline 8 & 94 & 163 & 75.8 & 1.730 & 0.8063 & 109 & 1 & 0.5 \\
\hline 9 & 123 & 158 & 58.7 & 1.280 & 0.4772 & 109 & 1 & 0.3 \\
\hline 10 & 110 & 155 & 71.3 & 1.410 & 0.6481 & 109 & 1 & 0.4 \\
\hline
\end{tabular}

Note: 1-10: principal enterprises which produce castor oil refinery. Co-var number is 304.42. 
The production frontier for years was measured using the best performance of companies. The apparently weak format of frontier was because in many years of harvesting the small farm which acted as input, had zero production. However, after 2003 the evolution shows that almost all states in the Northeastern region in Brazil are participating positively in the composition of the frontier. The strong correlation between the production and $\mathrm{X}_{1}$ :

Graphic 4: Production frontier by harvesting (input X1).

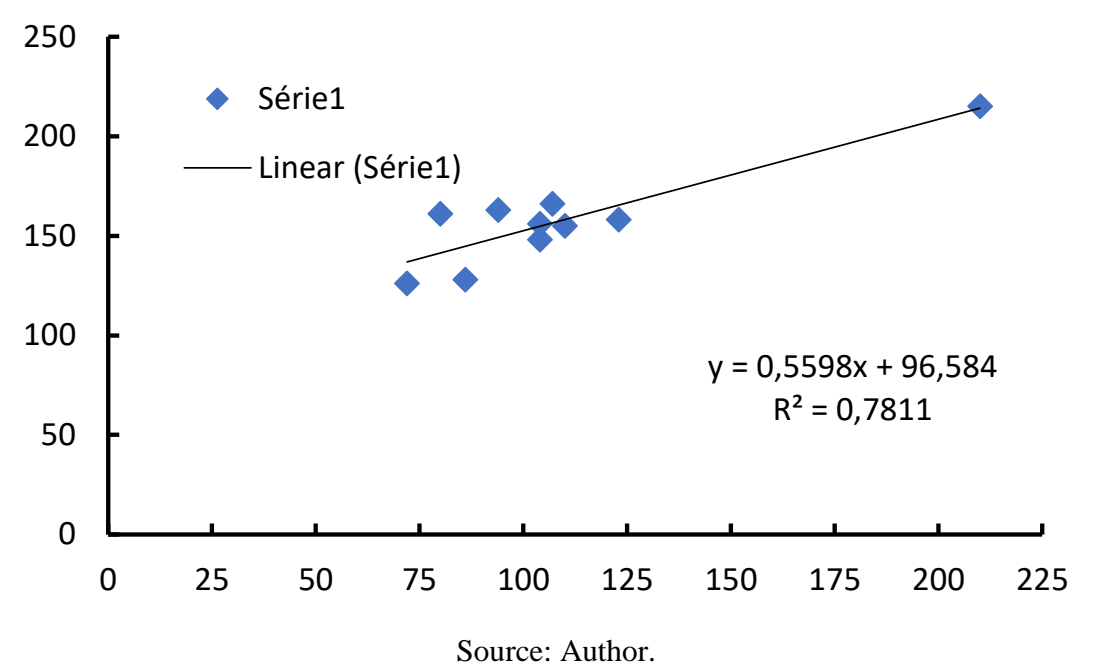

The values of $\mu$ and $v$ assume a modified trans logarithmic stochastic frontier production function, when as estimated of the technical efficiencies of individual firms in Brazil. It was found that was not an adequate representation for describing the value of the castor bean crop, given the specifications of the translog model. The variance random effects of the component variability of the value of the production. Individual technical efficiencies ranged from about 0.75 to 0.95 , in the case of the castor bean oil in Brazil, in this exercise was 0.4041.

Graphic 5: Classical frontier production.

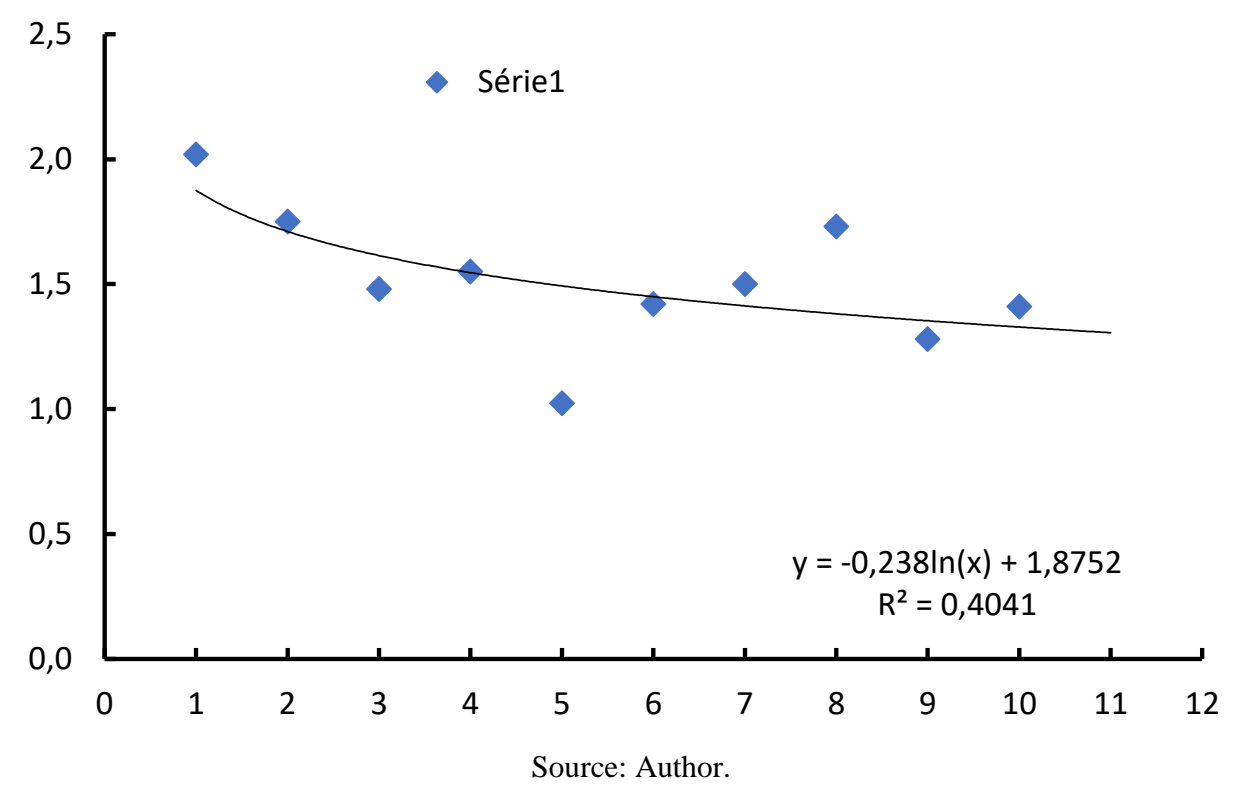


Analyzing the correlation between the input " $\mathrm{X}_{1}$ " in the DEA matrix is possible to correlate with the input "harvesting by area". This low correlation, in the beginning, expresses that some small farms non efficient can be eliminated from the federal program and the ones that have the best performances could replace it by output "movement harvesting". It does mean that the strongest will exclude these wrecks and the efficiency of the curb will be calculated by three inputs (area, expertise and anterior production) and also it will have two outputs (harvesting by area and mechanization).

\section{Conclusion}

Brazil has one of the cleanest energy matrices in the world, with $35.9 \%$ of it being composed of renewable energy, while the world average is only $13.5 \%$. The concept of "renewable" energy should be discussed more that takes into account the negative effects of these sources, including on land use. Biofuels are often treated as carbon neutral, here used in the sense that they do not contribute to the greenhouse effect in the atmosphere. That's because when they are burned, the carbon dioxide released is equivalent to absorbed by plants during their development fields. In order to combine important strategies and procedures with traditional practices of genetic and biological resources conservation related to the communities indigenous, Brazil has been showing in many different ways that innovation means conservation, valuing and sustainable use of biodiversity resources in situ to optimize participatory breeding and extraction management.

From an empirical point of view, the specific objective of the study was to understand the political-institutional arrangement of a public policy that, in the social and productive inclusion and also industrial and technological development, stands out for seeking to match the demands of democratic capacity - which translates into for the participation of both the Legislative and different social actors in its formulation, implementation and control process - with the presence of an apparatus administrative technician responsible for coordinating and providing the necessary instruments for its viability. It is the PNPB, an intersectoral federal public policy, launched in December 2004, which aims to sustainably implement the production and the use of biodiesel in the national territory, in order to generate employment and income in the countryside and to promote regional development. The PNPB, in addition to stimulating production and the use of biodiesel through the mandatory and gradual blending, created a market incentive as well for industry to acquire from the small farmers land the raw material needed for the production of biodiesel.

In the present study we used the Analysis Data envelopment (DEA) to evaluate the frontier of castor bean seed from 1990-2010. The purpose of the article was identifying the best units' markets (firms) in those years. So 10 companies were chosen by applying the boundary inverted, which also allowed the evaluation points in which the performance of DMU was not as good. Thus, the border composite indicated the company with better performance. The shape of the frontier production does not allow one business efficiency to reach only due to its specialization. This explains the low performance of some companies' efficient DEA when evaluated by classic inverted frontier. In 2005, we highlighted the performance of two companies and effectively held the first positions after applying the inverted border.

The amount of output reveals in some years the importance of choice of hectares and year/harvesting mainly executives. The region localization provided a greater in term of choice in this analysis, northeastern Brazil.

Furthermore, the method presented here for determination of benchmarks and anti-benchmark should be improved in order to make it more precise. The way was used, without further refinement, the method allowed a DMU to be considered the best benchmark. This result is contrary to common sense, as a consequence explained by the best performance of the companies studied.

Sum it up, the first idea here was to show a particular importance of the castor bean oil as a source of green energy and specifically as a biofuel. The fundamental importance of castor bean oil for future generations is pretty much a consequence of 
political decisions as was in Brazil. In the beginning of this presentation, it was shown the numerous relationships between the small farmland and its cultivar. The Brazilian plan solves two major problems: to consider that "mamona" is a crop of northeast Brazil and second to increase the power of revenue in that region.

The second idea came up when the production growth results and levels of efficiency of castor bean. The weak relation found is a matter result of the effect of late POLICIES decisions to accelerate the growth of this cultivar. The entrance of states such as Rio Grande do Norte and lately the highest amount of funds to the state of Ceara reflected, partly, the difficult correlation that was explained here.

\section{References}

Agência Nacional de Petróleo, Gás Natural E Biocombustíveis (ANP). Dados Estatísticos, Página http://www.anp.gov.br em 15/03/2005.

Agência Nacional de Petróleo, Gás Natural e Biocombustíveis (ANP). Biodiesel: estratégias para produção e uso no Brasil. In: Biodiesel: estratégias para produção e uso no Brasil, 2005, São Paulo: Unicorp, 26-27, abr. 2005. Anais... v.1, p.1-23.

Assis, A. N. de. A concepção do campo organizacional sustentável sob a ótica da complexidade: uma análise do modulo I do programa Pró-Guaiba. 2004. 72f. Dissertação (Mestrado em Administração) - Programa de Pós-Graduação em

Administração, Escola de Administração, Universidade Federal do Rio Grande do Sul, Porto Alegre, 2004.

Associação Brasileira das Indústrias de Óleos Vegetais (ABIOVE). Seminário Biodiesel no Rio Grande do Sul. In: Seminário Biodiesel no Rio Grande Do Sul, 2005, Canoas: Refap, 30, mai. 2002. Anais... v.1, p. 1-12.

Casa Cívil da Presidência da República. Biodiesel: estratégias para produção e uso no Brasil. In: Biodiesel: estratégias para produção e uso no Brasil, 2005, São Paulo: Unicorp, 26-27, abr. 2005. Anais... v.1, p. 24-33.

Charnes, A.; Cooper, W. W. \& Rhodes, E (1978). Measuring the efficiency of decision-making units, European Journal of Operational Research, Vol. 2, p. 429444, em 24/01/2010 - Published in february, 02, 2010.

Counort, A. A. (1897) Researches into the Mathematical Principles of the Theory of Wealth, New York and London: The Macmillan Company, 213p.

Ferres, D. Análise integrada dos custos de produção e comercialização do biodiesel no Brasil. In: Seminário Internacional sobre Biodiesel (ABIOVE / TECPAR) 2003 ,

FIscher, G.; Schrattenholzer, L. Global bioenergy potentials through 2050. Biomass \& Bioenergy, Pergamon, v.20, n.3, p. 151-159, mar., 2001.

Goldemberg, J. et al. Ethanol learning curve - the Brazilian experience. Biomass \& Bioenergy, Pergamon, v.26, n.3, p. 301-304, jun., 2005.

Giudicianni, P.; Pindozzi, S.; Grottola, C.M.; Stanzione, F.; Faugno, S.; Fagnano, M.; Fiorentino, N.; Ragucci, R. Pyrolysis for exploitation of biomasses selected for soil phytoremediation: Characterization of gaseous and solid products. Waste Manag. 2017, 61, 288-299. [CrossRef] 13.

Grottola, C. M.; Giudicianni, P.; Pindozzi, S.; Stanzione, F.; Faugno, S.; Fagnano, M.; Fiorentino, N.; Ragucci, R. Steam assisted slow pyrolysis of contaminated biomasses: Effect of plant parts and process temperature on heavy metals fate. Waste Manag. 2019, 85, 232-241. [CrossRef] 14.

Isla, M. A; Irazoqui, H. A. Glicerina: Coproducto del processo de transesterificación. Libro de oro de A\&G, Buenos Aires, 2003

Knothe, G. Historical perspectives on vegetable oil-based diesel fuels. Inform, AOCS, Nov. 2001.

Laboratório de Desenvolvimento de Tecnologias Limpas (LADETEL / USP-RP). Biodiesel: estratégias para produção e uso no Brasil. In: biodiesel: estratégias para produção e uso no Brasil, 2005, São Paulo: Unicorp, 26-27, abr. 2005. Anais... v.1, p. 34-37.

Ministério do Desenvolvimento Agrário (MDA). Seminário Biodiesel no Rio Grande do Sul. In: Seminário Biodiesel no Rio Grande do Sul, 2005, Canoas: Refap, 30, mai. 2002. Anais... v.1, p. 13-22.

Parente, E. J.de S. et al. Biodiesel: uma aventura tecnológica num pais engraçado. Fortaleza: Tecbio, 2003. 68p.

Pedroti, P. M. Os desafios do desenvolvimento e da inclusão social: o caso do arranjo político-institucional do Programa Nacional de Produção e Uso do Biodiese, BNDES, 2011.

Plá, J. A. Perspectivas do biodiesel no Brasil. Indicadores Econômicos FEE, Porto Alegre, v.30, n.2, p.179-190, set. 2002.

Pires, A. A Energia Além do Petróleo. In: Anuário Exame 2004-2005, infra-estrutura. Editora Abril, 2004.

Presidente da Repùblica. Lei N $\mathrm{N}^{\circ}$ 11.097, DE 13 DE JANEIRO DE 2005. Disponível em: <https://www.planalto.gov.br/ccivil_03/_Ato200406/2005/Lei/L11097.htm>. Acesso em: 27 de jan. de 2005.

Ramos, L. P. et al. Biodiesel: Um Projeto de sustentabilidade econômica e sócio-ambiental para o Brasil. Revista biotecnologia \& desenvolvimento, São Paulo, v. 31, jul./dez., 2003.

Severino, L. S., et al. A Review on the challenges for increased production of castor. Agron. J. 104:853-880. doi:10.2134/agronj2011.0210. 2012. 